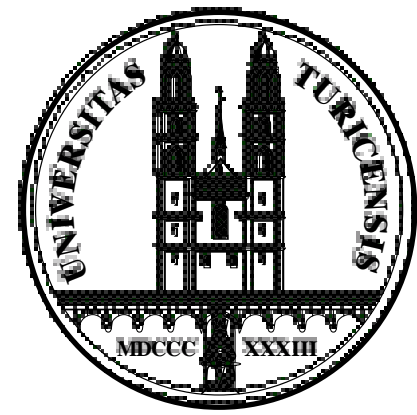

Institute for Empirical Research in Economics

University of Zurich

Working Paper Series

ISSN 1424-0459

Working Paper No. 28

Managerial Power and Compensation

Bruno S. Frey and Marcel Kucher

December 1999 


\title{
MANAGERIAL POWER AND COMPENSATION
}

by

\author{
Bruno S. Frey and Marcel Kucher \\ University of Zurich*
}

\begin{abstract}
According to the widely used Managerial Power Model, a higher hierarchical position with associated higher power leads to higher compensation. In contrast, the Compensating Wage Differentials Model argues that there is a non-positive relationship between positional power and total compensation. Both power and income yield utility and in equilibrium managers are prepared to trade-off the two elements. The two opposing propositions are tested using a large survey data set from Switzerland. The results suggest that power positions do not yield higher compensation. Rather, there is a non-positive relationship between power position and compensation, if one takes into account all relevant factors influencing total compensation.
\end{abstract}

Keywords: Power, Managerial Compensation, Compensating Wage Differentials.

JEL-Codes: A12, J31, M12

\footnotetext{
* The authors work at the Institute for Empirical Economic Research, University of Zurich, Bluemlisalpstrasse 10, 8006 Zurich, Switzerland, Tel.: +41-1-634 37 28, Fax: +41-1-634 49 07, E-mail: bsfrey@ unizh.ch, kucher@iew.unizh.ch. They are grateful for helpful comments from Iris Bohnet, Reiner Eichenberger and Reto Jegen.
} 


\section{MANAGERIAL POWER AND COMPENSATION}

\section{Introduction}

A positive relationship between power, and in particular managerial power, and compensation is generally accepted as a matter of course. That managers receive a higher compensation the more power they can exert, i.e. the higher their position, is common sense. It is also supported by a large amount of scientific literature dealing with power, which is "defined here as the capacity of individual actors to exert their will" (Finkelstein 1992: 506). Many other authors have used a similar definition (e.g. Hickson, Lee, Schneck and Pennings, 1971; Pfeffer, 1981) and have emphasized the importance of this concept in order to understand the behavior of firms and other organizations (e.g. Allison, 1971; Blau 1964; Bower and Doz, 1979; Eisenhardt and Bourgeios, 1988; Hinings, Hickson, Pennings and Schneck, 1974; Pfeffer, 1991; Pfeffer and Allison, 1992; Rothschild, 1971). Much of the literature concentrates on chief executives' power and compensation (e.g. Barkema and Pennings 1998; Finkelstein and Hambrick 1988, 1989, 1996; Hambrick and Finkelstein 1995; Wade, O'Reilly and Chandradat 1990). The more general "Managerial Power Model" (Lambert, Larcher et al. 1993: 442) distinguishes between four sources of power (organizational position, information control, personal wealth, nomination of "loyal" individuals to the board) but "[r] egardless of the precise source of power, the managerialpower model predicts a positive association between the level of an executive's power and the level of compensation" (Lambert, Larcher et al. 1993: 442).

The proposition of a positive relationship between managerial power and compensation has been subjected to a rigorous empirical test, using a sample of 303 large publicly traded U.S. firms (Lambert, Larcher et al. 1993). These manufacturing and service firms span a large number of industrial sectors in the economy (42 different two-digit standard industrial classification codes). The median corporate sales (in 1990 dollars) are over \$3,000 million and the median number of employees is 25,000 . 
The outcome of the test is clear-cut: "Our primary results . . show that the level of corporate and business-unit executive compensation is positively related to the number of employees supervised by the executive" (p. 452). Managers who have the potential to influence the behavior of a larger number of subordinates have higher actual compensation payments.

\section{An alternative view}

This paper presents an alternative view of the relationship between managerial power and compensation. Following the fundamental economic principle of compensating wage differentials (see e.g. Thaler and Rosen, 1976; Brown, 1980 or, for a literature survey, Rosen, 1986), employees who derive higher than average utility from part of their work (or from their income) have to be compensated less. Certainly "power", in the form of being able to direct and give orders to subordinates, belongs to this category (a good survey on the importance of power as a motivator for managers is given in McClelland and Burnham, 1995). The (reasonable) assumption behind this reasoning is that managers enjoy both income $(Y)$ and power $(P)$, i.e. their utility function is of the form $U=U(Y, P)$, with both first derivatives being non-negative. Therefore, having more power can compensate a lower income, and having less power can be compensated by a higher income, while utility remains constant. As a result, in equilibrium managers with positions of higher power receive a lower (or at least not higher) compensation.

Measuring power by hierarchical position (i.e. by the number of subordinates), as done by Lambert, Larcher and Weigelt (1993), the "Compensating Wage Differentials Model" yields a quite different prediction than the "Managerial Power Model":

\section{Proposition:}

The number of a manager's subordinates is non-positively related to his or her total compensation, ceteris paribus.

The ceteris paribus condition is crucially important for our proposition. Persons in higher positions receive higher incomes because they have, on average, higher education, have been associated with the firm for a longer period of time, are predominantly male etc. Our proposition thus refers to the "pure" effect of power (derived from a certain position) on compensation. 
The next section presents the data with which the proposition is tested. The empirical (econometric) estimates are presented in the following section. We re-estimate the Managerial Power Model with our data (including a large number of control variables to ensure the ceteris paribus condition) and use the results to test our own hypothesis. The last section draws conclusions.

\section{The Data}

The hypothesis developed is tested using data from the 1996 Swiss Labor Force Survey (SLFS). It includes roughly 16'000 respondents, who were asked detailed questions about their incomes, work experience, education and other variables concerning their work-life, as well as demographic characteristics. We restrict our attention to employees only. By doing so, we exclude people in education, the retired and unemployed, as well as the self-employed, whose income tends to understate the flow of monetary benefits from their jobs (this is mainly due to the Swiss tax system, which allows the self-employed to deduct many expenses). We also exclude those that refused to report their incomes. This, of course, might introduce a problem of selectivity. However, we believe that it is unlikely that the variables of interest are correlated with the probability of making or refusing to make an income statement.

The SLFS focuses on total compensation. Therefore, the survey also includes questions on bonuses or non-monetary compensation (like company cars or company apartments). SLFS attributes monetary values to all these items to get a detailed picture of total compensation. To make wages even more comparable, we moreover correct for differences in weekly working time, vacation and overtime. The resulting average wage per hour is $39.65 \mathrm{Swiss}$ Francs, with a maximum of 979.40 and a minimum of 0.10 Swiss Francs. Since an hourly wage of 0.10 Swiss Francs is not credible, we excluded all respondents that stated a wage per hour of less than five Swiss Francs. By doing so, we exclude another 54 people, so that the final sample comprises 6966 observations $^{1}$.

Exactly 2400 people in our sample (or roughly 34 percent of the respondents) have at least one subordinate and are therefore considered superiors. The corrected average wage per hour of the

\footnotetext{
${ }^{1}$ Excluding these people, however, leaves the average wage almost unaltered, and does not have any significant influences on the results.
} 
superiors is 46.95 Swiss Francs. Comparing this to the average wage of the non-superiors (which is 36.25 ) reveals that superiors earn about 29 percent more on average.

Approximately one third of the respondents (35 percent) work for companies with more that 100 employees, only 10 percent work in very small companies (up to 30 employees), while the majority works for middle-sized companies with 30 to 100 employees. This corresponds roughly to the Swiss industry structure. This stands in sharp contrast to most studies on management compensation, which usually concentrate on (very) large firms and do not draw a representative sample as we do here. However, we believe that working with a representative sample yields a much more comprehensive picture than concentrating on a very special part of the industry only.

Of course, representativeness not only refers to the firm size but also to the industries that are included in the sample. Companies were grouped according to the industry classification provided by the Swiss Federal Statistical Office (SFSO). We include this classification in our estimates in order to eliminate industry specific effects.

\section{Estimates}

All our estimates are weighted using the cross sections weights provided by SLFS. The weights are necessary to correct for the representativeness, since the SLFS does not use a random, but rather a weighted sample.

The results of a weighted OLS regression explaining wages in Switzerland are reported in table 1. We use the logarithm of wages as the dependent variable. The coefficients can therefore be interpreted as the percentage changes in hourly wages for an individual with the respective characteristics over the wage of the reference group (male Swiss with just compulsory education not working in one of the sectors controlled for). As Lambert, Larcher and Weigelt (1993) do, we include company size and dummies for each sector in the regression. Along with additional control variables for Saturday, Sunday and night work the latter are not shown in order to save space.

Insert Table 1 about here 
The first two columns of table 1 refer to the Managerial Power Model as specified by Lambert, Larcher and Weigelt (1993). They exhibit the estimated coefficients in the first column and the tstatistics in the second one. The estimation results appear to be consistent with the Managerial Power Model: Moving up the hierarchy and therewith having more subordinates and power is, in all cases, associated with a statistically significant increasing compensation (all t-values far exceed the level of 2). In most cases, the increases in the coefficients are statistically significant, the only exception being the coefficient for having between 49 and 99 inferiors (Sup99) and the one for having more that 100 inferiors (Sup100) which can statistically not be distinguished. The equation accounts for $18 \%$ of the variation in compensation, which, for a cross section with individual data, is quite satisfactory.

However, the model specified by Lambert, Larcher and Weigelt lacks one very important feature: The effects of power on compensation are not estimated ceteris paribus, which means that they do not control for other (individual) characteristics which may have an impact on compensation ${ }^{2}$. In particular, they cannot (because of the data set they use) control for education and tenure or experience. It is well known that all of these variables are strongly correlated with the hierarchical position (and with the number of subordinates), and therefore most likely have an important impact on individual compensation. Columns (3) and (4) of table 1 exhibit the estimated coefficients and t-statistics of our Compensating Wage Differentials Model, which includes the control variables just mentioned. As suggested, this improved model reveals quite a different relationship between power (position) and compensation. In line with the ceteris paribus condition, we control for tenure, experience and education as well as gender and nationality.

The effects of hierarchical position on compensation are again statistically highly significant and consistent with our hypothesis: Moving up the hierarchy (i.e. having more superiors) does not lead to higher compensation. Managers with five subordinates receive a $13 \%$ higher wage than workers without subordinates, but essentially the same increase (a 14\% increase) holds for managers with 10 subordinates, with 49 subordinates or with 100 and more subordinates. Indeed, managers having between 20 and 49 subordinates have a lower increase (only seven percent) compared to non-managers than those having between 10 and 20 inferiors (who earn on average 14 percent more). This is a statistically significant difference compared to other hierarchical positions. Overall, our estimates, which control for important factors besides power, suggest that 
power is not associated with higher income. According to our interpretation of this result, there are two countervailing influences acting on manager compensation: On the one hand, having inferiors increases responsibility, which should be compensated by higher wages. On the other hand, superiors at the same time enjoy comparatively more power. Hence, they are prepared to work for a lower wage. This compensates for the effect of responsibility, so that the extra wage received stays roughly the same, independent of whether one is a superior of one or 99 employees. If anything, "pure" power in the form specified by us is consistent with the Compensating Wage Differentials Model.

Tenure and experience (measured by the number of years in the current firm, and in the overall labor market, respectively) enter the equation in linear as well as in squared terms (in order to allow for a non-linear relation between the two time period variables). All four control variables are statistically significant on the $99 \%$ level. The coefficient values indicate that both tenure and experience have a positive influence on total compensation. The negative coefficients for the squared terms indicate that there is a maximum beyond which additional years of experience or tenure have negative effects on compensation. However, this maximum is most likely not to be reached by most people, as it lies at 63 years of tenure and 77 years of experience respectively.

A total of eight variables control for various levels of education. All levels indicated here refer to the highest formal educational level achieved. The reference group is a male worker with just compulsory education. Education I to IV refer to compulsory education plus various forms of secondary on- or off-the-job education. They all exert a statistically highly significant positive effect on compensation. For example, having a university degree increases total compensation by 51 percent on average.

The control variable for gender suggests that being female is associated with a statistically highly significant $11 \%$ lower compensation. This reflects the by now well-known gender discrimination. Being married is associated with higher compensation, which may be attributed to a selection effect. The final two control variables suggest that being a temporary resident (in Switzerland permit B), or living in the country with a "Green Card" (permit C), is associated with a statistically significant lower income.

\footnotetext{
2 The only controls they introduce are industrial sector and firm size which both have an important impact on compensation.
} 
The Compensating Wage Differentials Model accounts for $36 \%$ of the variance, according to the adjusted R-squared, which is twice as much as the Managerial Power Model and extraordinarily high for a cross-section analysis based on individual data.

As the sample of Lambert, Larcher et al. (1993) consists of superiors only, colums (5) and (6) exhibit the corresponding estimates for our data set. Excluding non-superiors reduces the sample to exactly 2400 observations. As can be seen, the qualitative results of the estimations remain unaffected: A higher position, and thus higher power, is still not associated with higher total compensation. The results are therefore again consistent with the proposition derived from the Compensating Wage Differentials Model.

\section{Conclusions}

The Managerial Power Model suggests that higher management position and therefore more power, is associated with higher total compensation. This paper suggests an alternative view: A position with more power yields higher utility, and therefore in equilibrium managers are prepared to trade-off more power with lower total compensation, ceteris paribus. Using a large data set from Switzerland, we demonstrate that higher managerial position is not associated with higher total compensation. The positive correlation found in some previous studies is due to incomplete controlling for individual characteristics. Overall, the Compensating Wage Differentials Model is consistent with the data, while the Managerial Power Model is not. 


\section{References}

Allison, G.T. (1971). Essence of Decision: Explaining the Cuban Missile Crisis. Boston: Little, Brown.

Barkema, Harry G. and Johannes M. Pennings (1998). Top Management Pay: Impact of Overt and Covert Power. Organization Studies 19: 975-1003.

Blau, Peter M. (1964). Exchange and Power in Social Life. New York: Wiley.

Bower, J.L. and Y. Doz (1979). Strategic Formulation: A Social and Political Process. In: D. E. Schendel and C. W. Hofer (Eds), Strategic Management: A New View of Business Policy and Planning. Boston: Little, Brown: 152-165.

Brown, Charles (1980). Equalizing Differences in the Labor Market. Quarterly Journal of Economics 94: 113-34.

Eisenhardt, K. and L. J. Bourgeois (1988). Politics of strategic decision making in high-velocity environments: Towards a midrange theory. Academy of Management Journal 31: 737-770.

Finkelstein, Sidney (1992). Power in Top Management Teams: Dimensions, Measurement and Validation. Academy of Management Journal 35: 505-538.

Finkelstein, Sidney and Donald C. Hambrick (1988). Chief Executive Compensation: A Synthesis and Reconciliation. Strategic Management Journal 9: 543-558.

Finkelstein, Sidney and Donald C. Hambrick (1989). Chief Executive Compensation: A Study of the Interxection of Markets and Political Processes. Strategic Management Journal 10: 121134.

Finkelstein, Sidney and Donald C. Hambrick (1996). Strategic Leadership: Top Executives and their Organizations. Minneapolis: West Publishing Company.

Hambrick, Donald C. and Sidney Finkelstein (1995). The Effects of Ownership Structure on Conditionsat the top: The Case of CEO Pay Raises. Strategic Management Journal 16: 175194.

Hickson, David J., Robin C. Hinings, Charles A. Lee, Rodney E. Schneck and Johannes M. Pennings (1971). A Strategic Contingencies`Theory of Interorganizational Power. Administrative Science Quarterly 16: 216-229. 
Hinings, C.R., D. J. Hickson, J. M. Pennings and R. E. Schneck (1974). Structural Conditions of Intraorganizational Power. Administrative Science Quarterly 19: 22-44.

Lambert, Richard A. and David F. Larcher and Keith Weigelt (1993). The Structure of Organizational Incentives. Administrative Science Quarterly 38: 438-461.

Pfeffer, (1981). Power in Organizations. Boston: Pitman.

Pfeffer, J. (1992). Managing with Power. Boston: Harvard Business School Press .

Pfeffer, Jeffrey and Konrad Allison (1991). The Effect of Individual Power on Earnings. Work and Occupation 18/4: 382-414.

Rosen, Sherwin (1986). The Theory of Equalizing Differences. In: Orley Ashenfelter and Richard Layard (eds) Handbook of Labor Economics. Amsterdam: North-Holland: 641-92.

Rothschild, Kurt W. (1971). Power in Economics. Harmondsworth: Penguin.

Thaler, Richard H. and Sherwin Rosen (1976). The Value of Saving a Life: Evidence from the Market. In: Nestor E. Terleckyj (ed.) Household Production and Consumption. Cambridge, Mass.: National Bureau of Economic Research.

Wade James, Charles A. O'Reilly and Ike Chandradat (1990). Golden Parachutes: CEOs and the Exercise of Social Influence. Administrative Science Quarterly 35: 587-603. 


\section{Table 1: Estimated Compensation Equation \\ Dependent variable is $\log ($ wage $)$}

\begin{tabular}{|c|c|c|c|c|c|c|}
\hline \multirow[t]{2}{*}{ Variables $^{1}$} & \multicolumn{2}{|c|}{$\begin{array}{l}\text { Managerial Power } \\
\text { Model } \\
\text { (all respondents) }\end{array}$} & \multicolumn{2}{|c|}{$\begin{array}{l}\text { Compensating Wage } \\
\text { Differentials Model } \\
\text { (all respondents) }\end{array}$} & \multicolumn{2}{|c|}{$\begin{array}{l}\text { Compensating Wage } \\
\text { Differentials Model } \\
\text { (superiors only) }\end{array}$} \\
\hline & $\begin{array}{l}\text { Coefficient } \\
\text { (1) }\end{array}$ & $\begin{array}{l}\text { t-Statistic } \\
\text { (2) }\end{array}$ & $\begin{array}{l}\text { Coefficient } \\
\text { (3) }\end{array}$ & $\begin{array}{l}\text { t-Statistic } \\
\text { (4) }\end{array}$ & $\begin{array}{l}\text { Coefficient } \\
\text { (5) }\end{array}$ & $\begin{array}{l}\text { t-Statistic } \\
\text { (6) }\end{array}$ \\
\hline Constant & 3.27 & 247.11 & 2.99 & 139.34 & 3.18 & 76.98 \\
\hline Sup $5^{2}$ & 0.29 & 19.80 & 0.13 & 9.80 & \multicolumn{2}{|c|}{ Reference Group } \\
\hline Sup10 & 0.38 & 16.80 & 0.14 & 6.48 & -0.03 & -1.17 \\
\hline Sup20 & 0.42 & 15.71 & 0.07 & 2.88 & -0.08 & -3.28 \\
\hline Sup49 & 0.46 & 14.06 & 0.14 & 4.67 & -0.03 & -0.99 \\
\hline Sup99 & 0.59 & 9.36 & 0.18 & 3.28 & 0.05 & 0.92 \\
\hline Sup100 & 0.56 & 7.81 & 0.14 & 2.74 & -0.003 & -0.06 \\
\hline Tenure & & & 0.01 & 9.44 & 0.005 & 2.99 \\
\hline Tenure squared & & & -0.0001 & -6.60 & -0.00008 & -2.40 \\
\hline Experience & & & 0.02 & 15.09 & 0.017 & 7.45 \\
\hline Experience squared & & & -0.0003 & -11.53 & -0.0002 & -5.05 \\
\hline Company Size $20^{3}$ & 0.12 & 5.47 & 0.11 & 5.71 & 0.12 & 3.66 \\
\hline Company Size 49 & 0.14 & 8.71 & 0.06 & 4.12 & 0.17 & 7.52 \\
\hline Company Size 99 & 0.11 & 5.86 & 0.08 & 4.84 & 0.17 & 6.60 \\
\hline Company Size 100 & 0.24 & 17.08 & 0.16 & 13.00 & 0.23 & 10.87 \\
\hline Education $\mathrm{I}^{4}$ & & & 0.15 & 6.77 & 0.05 & 1.18 \\
\hline Education II & & & 0.19 & 4.70 & 0.18 & 1.91 \\
\hline Education III & & & 0.25 & 10.21 & 0.09 & 2.82 \\
\hline Education IV & & & 0.12 & 3.19 & -0.01 & -0.16 \\
\hline Apprenticeship & & & 0.07 & 4.98 & -0.02 & -0.84 \\
\hline Matura & & & 0.27 & 12.01 & 0.16 & 3.54 \\
\hline Tech & & & 0.31 & 11.91 & 0.22 & 5.88 \\
\hline University & & & 0.51 & 25.63 & 0.37 & 11.30 \\
\hline Female & & & -0.11 & -9.30 & -0.19 & -8.82 \\
\hline Married & & & 0.08 & 7.92 & 0.11 & 5.88 \\
\hline Temporary Resident & & & -0.17 & -7.93 & -0.04 & -2.07 \\
\hline Green Card & & & -0.10 & -12.43 & -0.04 & -1.69 \\
\hline Included Observations & 6966 & & 6966 & & 2400 & \\
\hline $\begin{array}{l}\text { Unweighted Adjusted } \\
\mathrm{R}^{2}\end{array}$ & 0.18 & & 0.36 & & 0.38 & \\
\hline
\end{tabular}

Notes:

1. Other control variables included in all regressions: Saturday, Sunday and night work and dummy variables for each sector.

2. Sup5 means that the respective respondent has up to five people working for her. Sup10 stands for a manager who has 5 to 10 employees working for her. Sup100 means that a person has 100 and more subordinates.

3. Company Size 20 means that the respective respondent works for a company that has up to 20 employees. Company Size 49 stands for companies with 21 to 49 employees. Company Size 100 means that a firm has 100 and more employees.

4. Education I to IV stand for different forms of additional education following compulsory education. They all last one to two years.

Data source: Swiss Labor Force Survey, 1996. 